\title{
Survey and Population Density of Land Snails under Different Conditions at Qalubia and Sharkia Governorates
}

Gad H. H. Rady ${ }^{1}$, Maha M. Fouad ${ }^{2}$, Mohamed Gh. R. ${ }^{1}$ and Mostafa El. Mohamed ${ }^{2}$

1. Plant Protection Department, Faculty of Agriculture, Benha University, Qalubia Governorate.

2. Plant Protection Research Institute, Agricultural Research Centre, Dokki,Giza,Egypt.

\begin{abstract}
The aim of this research is study the survey and effect soil components on population density and distribution of land snails in Kafr Al-Gammal and Kafer Hamza villages (Qalubia Governorate), and Sunhot and Adleya villages (Sharkia Governorate). Survey studies revealed that four species of land snails, Monacha cartusiana, Eobaina vermiculata, Succinea putris and Cochlicella acuta were found in the two governorates. All species were found in Adleya and Kafr Al- Gammal villages, while the two species, M. cartusiana and S. Putris, were found in Kafr Hamza village, whereas, M. cartusiana only was found in Sunhot village. These findings indicated that the population density of land snails differed from one locality to another. The highest population was recorded in Adleya village, while M. cartusiana was the most predominant species. On the other hand, soil analysis showed that the population density of land snails were high in loam soil, especially $M$. cartusiana, followed by sandy loam but the population density of E. vermiculata was high in sandy loam. In addition the low population density of land snails was in silty loam. On the other hand, the chemical analysis of soil showed that the number of snails increased with the increase of calcium, while decreased with high values of $\mathrm{pH}$ and $\mathrm{EC}$ (Electrical conductivity) in soil.
\end{abstract}

Key words: Land snails, survey, distribution, population density, analysis of soil.

\section{Introduction}

Snails represent one of the important groups of invertebrates in terrestrial ecosystems. Land snails belong to the second largest phylum, after arthropods, (Sandeepet al. 2012). Land snails constitute around six percent of the total species on earth,(Clark and May,2002).Terrestrial gastropods attack the leaves, roots, buds, flowers, and even the tree trunks, causing damage to the foliage and fruit of cultivated plants, (Awad et al.2012). The feeding activities of gastropods, as well as their soiling of fruits and crops with their excreted feces and mucus materials, during movement, lower the quality and size of the harvest, and damage crops in fields and gardens, (Awad,2014). As a result, undesirable smell is caused, which prevents both man and animals from feeding on these contaminated plants, (Shetaia et al. 2009). In addition, rotting agents, such as bacteria, and fungi, usually establish themselves at places where slugs or snails have fed, so fruits and vegetables, in storage, suffer further damage, (Shahawy et al. 2008). In Egypt, the destructiveness of gastropods is much greater today than it was in former times, (Mortada, 2002). To control this pest, it is necessary to understand and investigate the reaction between their population density, and the surrounding conditions, such as soil temperature, soil structure, host plants, etc. Moreover, the perception of climate and environmental changes on the performance and availability of edible land snails was researched by (Giokas $\boldsymbol{e t}$ al. 2007 ), and ( Woogeng et al. 2013 ). In many studies on land snails, particular attention was paid to soil chemical parameters, as snails have high demand of calcium for shell formation. Calcium content of soil or litter, or $\mathrm{PH}$ value as another measure for calcium supply were concluded to be major factors determining snail species richness, and also snail density, ( Millar and Waite, 2002).

The present work was carried out, to throw light on the survey and population density of land snails in certain fields, vegetable crops, and fruit trees at Sharkia and Qalubia Governorates

\section{Materials and Methods}

The present work was carried out in four locations: Sunhot and Adleya villages at Sharkia Governorate, Kafr Al- Gammal and Kafer Hamza villages, at Qalubia Governorate. Survey and population density of land snails were recorded on Egyptian clover (Trifolium alexandrium), wheat (Triticum vulgare), lettuce (Lactuca sativa), tomato (Solanum copersicum), eggplant (Solanum melongena) orange trees (Citrus sinensis) and guava (Psidium guajava), throughout seasons of 2014to2016.

\section{Survey of land snails on different crops}

Survey of land snails was conducted to study the definition and distribution of land snail species attacking numerous host plants, cultivated at Sharkia and Qalubia Governorates, 
during the period from February 2014 to May 2015. The survey was undertaken on various host plant species. Samples were taken in the early morning using the quadrate sample size $0.25 \mathrm{~m}^{2}$, or a single tree ( Eshra,2013). Five random samples were taken from each crop in the surveyed localities. All snails found on plants or on soil surface in the quadrate were counted and transferred in muslin cloth bags to the laboratory( Asran,2001), and classified according to Godan's Key of identification for Central European Best Gastropods.(1983).This procedure was done once monthly during the trial period.

\section{Population density of land snails.}

The population density of land snails were determined it in the chosen fields cultivated with egyptian clover, wheat, lettuce, tomato, eggplant and trees of orange and guava heavily infested with snails in Sunhot and Adleya villages, at Sharkia Governorate, and Kafr AlGammal and Kafr Hamza villages, at Qalubia Governorate, during two successive growing seasons from February to May2015 and 2016. Half of feddan was selected for each crop. Five replicates consisting of five trees, or quadrate sample area of $0.25 \mathrm{~m}^{2}$ were randomly examined once per month in the early morning. All snails, found on plants or soil surfaces in the quadrate or the single tree, were counted and left in their initial places(Baker, 1988).From the same site samples of the collected snails, soil samples(500 gm/sample)were taken at depth of $5 \mathrm{~cm}$, then transferred in plastic bags for mechanical and chemical analysis. Absolute population density and relative population density of the individual's species were calculated as follows:
Absolute population density $=$

Total number of individuals of species

Number of samples containing this species

Relative population density $=$

Number of individuals of species $\quad \times 100$

Sum of individuals of all this species

\section{Results and Discussion}

1- Survey and population density of the land snails at Qalubia and Sharkia Governorates.

Study of survey and population density of land snails species at Sharkia and Qalubia Governorates were showed in Table (1). Data indicated that Four land snails, Monacha cartusiana, Eobania vermiculata, Succinea putris and Cochlicella acuta are found in the two Governorates mentioned before. $M$. cartusiana, E. vermeculata and $C$. acuta belong to family Hellicidae, while $S$. putris belongs to family Succineidae. The land species $M$. cartusiana was the highest in total average of general population density (869.3indiv. with $80.4 \%$ ), while C.acuta was the lowest with (23.9indiv. and 2.2\%). For M. cartusiana, its population density in Qalubia Governorate was (482, 3indiv. with 86\%) higher than its population density in Sharkia Governorate (387indiv. with 74.5\%). However, the population density of E. vermiculata in Sharkia was highest with (86.9indiv. and 16.7\%). In addition, the recorded data cleared that $C$. acuta had the lowest population density for Sharkia and Qalubia Governorates both, meanwhile, $M$. cartusiana was the highest one.

Table 1.Survey and the mean number of population density of land snails at Qalubia and Sharkia Governorates.

\begin{tabular}{|c|c|c|c|c|c|c|}
\hline \multirow{3}{*}{$\begin{array}{l}\text { Governorate } \\
\text { Land snails }\end{array}$} & \multicolumn{6}{|c|}{ Mean number of snails per sample } \\
\hline & \multicolumn{2}{|c|}{ Qalubia } & \multicolumn{2}{|c|}{ Sharkia } & \multicolumn{2}{|c|}{ Total average } \\
\hline & Absolute & Relative & Absolute & Relative & Absolute & Relative \\
\hline Monacha cartusiana & 482.3 & $86 \%$ & 387 & $74.5 \%$ & 869.3 & $80.4 \%$ \\
\hline Eobania vermiculata & 42.2 & $7.5 \%$ & 86.9 & $16.7 \%$ & 129.1 & $12 \%$ \\
\hline Scciniea putris & 27.1 & $4.8 \%$ & 30.8 & $6 \%$ & 57.9 & $5.4 \%$ \\
\hline Cochlicella acuta & 9.4 & $1.7 \%$ & 14.5 & $2.8 \%$ & 23.9 & $2.2 \%$ \\
\hline Total average & 561 & & 519.2 & & 1080.2 & \\
\hline
\end{tabular}

\section{2- The distribution and population density of land snails at Qalubia and Sharkia Governorates.}

Data in Table (2) showed the distribution of different beneficence land snails in some villages of Qalubia and Sharkia Governorates. It is cleared that, at Sharkia Governorate, all identified species are found in Adleya village, and one specie $M$. cartusiana in Sunhot village. Adleya village was highly infested with the land snail M. cartusiana (273.5indiv. with $67.4 \%$ ) in comparison with other land snails, followed by $E$. vermculata (86.9indiv. with $21.4 \%)$, S. putris (30.8 indiv. With $7.6 \%$ ) and C. acuta (14.5 indiv. With $3.6 \%$ )

At Qalubia Governorate, results showed that, two land snails, $M$. cartusiana and $S$. putris were found in Kafr Hamza village, while four land snails species, $M$. cartusiana, $E$. 
vermiculata, S. putris and C. acuta were found in Kafr El-Gammal village. M. cartusiana had the highest population density (328.3 indiv. with $84.4 \%)$, followed by $E$. vermiculata $(42.2$ indiv. and 10.8\%). On the other hand, C. acuta didn't found in each of Kafer-Hamza and Sunhot villages, while $S$. putris snail was found in all tested villages excepted for Sunhot village.

Table 2.The distribution and population density of land snails in some villages of Qalubia and Sharkia Governorates.

\begin{tabular}{|c|c|c|c|c|c|c|c|c|}
\hline \multirow{4}{*}{$\begin{array}{l}\text { Village } \\
\text { Land snails }\end{array}$} & \multicolumn{8}{|c|}{ Mean number of snails per sample } \\
\hline & \multicolumn{4}{|c|}{ Qalubia } & \multicolumn{4}{|c|}{ Sharkia } \\
\hline & \multicolumn{2}{|c|}{ Kafr Hamza } & \multicolumn{2}{|c|}{ Kafr EL-Gammal } & \multicolumn{2}{|c|}{ Adleya } & \multicolumn{2}{|c|}{ Sunhot } \\
\hline & Absolute & Relative & Absolute & Relative & Absolute & Relative & Absolute & Relative \\
\hline Monacha cartusiana & 154 & 94.3 & 328.3 & 84.4 & 273.5 & 67.4 & 113.5 & 100 \\
\hline Eobania vermiculata & 0 & 0 & 42.2 & 10.8 & 86.9 & 21.4 & 0 & 0 \\
\hline Scciniea putris & 17.9 & 5.7 & 9.2 & 2.4 & 30.8 & 7.6 & 0 & 0 \\
\hline Cochlicella acuta & 0 & 0 & 9.4 & 2.4 & 14.5 & 3.6 & 0 & 0 \\
\hline Total average & 171.9 & & 389.1 & & 405.7 & & 113.5 & \\
\hline
\end{tabular}

\section{3- The distribution and population density of land snails on some host plants.}

Data in Table (3) revealed that $M$. cartusiana land snail was found on all host plants with total number of 434.4 indiv./samples. The highest average number was 176.1 indiv. on clover, and the lowest one was 10.2 indiv. on guava trees. In addition $E$. vermiculata was found on all host plants except for guava trees, whereas, the orange trees were the most affected by this snail 54.8 indiv., for $S$. putris land snail was found on clover, wheat, lettuce, guava trees, and orange trees with 10.8, $6.3, \quad 3, \quad 3.6$ and 5.6 indiv., respectively. However, it was not found on eggplant or tomato crops. C. acuta was appeared only on orange trees. Generally the highest number of land snails was found on clover with 190.3 indiv., followed by wheat 124.9indiv.and orange trees 117.8 indiv., while the lowest number of snails was observed on eggplant 19.1 indiv.. The previous results proved that $M$. cartusiana was the most abundant than other snail species. In addition, both clover and wheat crops were more infested by this snail than other crops. The orange trees were more infested by $E$. vermiculata than by other snail species. Through the results, we concluded that agricultural crops with dense vegetation cover are more suitable host for land snails, and protected them against weather and natural enemies.

In general, results revealed that Monacha cartusiana land snail was the predominant species in the two governorates, while Sunhot village (Sharkia Governorate) was the least infested with the land snail species.

These results are in agreement with those reported by Rady, et al. (2014), who stated that stating that Monacha cartusiana land snail was the predominant species on fields of vegetable crops in Ismailia and Sharkia governorates. On the other hand, population density of land snails differed from host plant to another. Mohamed.(2015) reported that ten land snails species, Eobania vermiculata (Muller), Theba pisana (Müller), Helicella vestalis (Pfeiffer), Cochlicella acuta (Müller), Monacha cartusiana (Müller), Monacha obstructa (Ferussac), Succinea putris (Linnaeus), Succinea oblonga (Draparnaud), Achatinidae (Linnaeus) and Oxychilus alliarius (Miller) were recorded on different vegetation, vegetable, fruit, ornamental plants in north East of Delta.

Table3.Population density and distribution of land snails on some host plants.

\begin{tabular}{|c|c|c|c|c|c|c|c|c|}
\hline \multirow[t]{2}{*}{ Land snails } & \multicolumn{8}{|c|}{ Host plants } \\
\hline & Clover & Wheat & Lettuce & Tomato & Eggplant & Guava & Orange & Total \\
\hline Monacha cartusiana & 176.1 & 115.9 & 47.5 & 21 & 18.3 & 10.2 & 45.4 & 434.4 \\
\hline Eobania vermiculata & 3.4 & 2.7 & 1.7 & 1.4 & 0.8 & $\mathbf{0}$ & 54.8 & 64.8 \\
\hline Sccinea putris & 10.8 & 6.3 & 3 & $\mathbf{0}$ & $\mathbf{0}$ & 3.6 & 5.6 & 29.3 \\
\hline Cochlicella acuta & $\mathbf{0}$ & $\mathbf{0}$ & $\mathbf{0}$ & $\mathbf{0}$ & $\mathbf{0}$ & $\mathbf{0}$ & 12 & 12 \\
\hline Total & 190.3 & 124.9 & 52.2 & 22.4 & 19.1 & 13.8 & 117.8 & \\
\hline
\end{tabular}

\section{4- Effect of soil type on the distribution and} population density of land snails.

\section{4-1- Effect of mechanical structure of soil.}

Data in Table (4) explain the relationship between the distribution and population density of land snails 
and mechanical structure of soil in the studied areas. The results revealed that the highest percentage of $M$. cartusiana was in Kafr Al-Gammal village, which has soil loam and consists of $39.68 \%$ sand, $46.7 \%$ silt, and $13.5 \%$ clay. In Adleya village, the average of snails was higher than the other villages. It had the highest percentage of E. vermiculata, $S$. putris and $C$. acuta $(67.2,53.2,60.4 \%)$ respectively, as its soil is sandy loam, and consists of $76.5 \%$ sand, $12.5 \%$ silt, and $10.96 \%$ clay. this may be due to the ease of drilling to lay eggs in light soil. The lowest percentage of snails was generally in Sunhot, which is characterized by silty loam soil, and consists of 23.96
$\%$ sand, $61.55 \%$ silt, and $13.03 \%$ clay. This may be due to the difficulty of drilling to lay eggs, because of the soil granules strength of cohesion, along with the difficulty of movement during drought or increase the water rate. The table indicates that numbers of both $E$. vermiculata and $C$. acuta are higher in sandy soil than in loam soil, whereas the numbers of $M$. catusiana are higher in loam soil.

Statistical analysis showed that the average general population density of snails is positively correlated with the proportion of sand, but negatively correlated with the percentage of both silt and clay in soil structure.

Table 4. Effect of Mechanical analysis of soil on the distribution and population density of land snails.

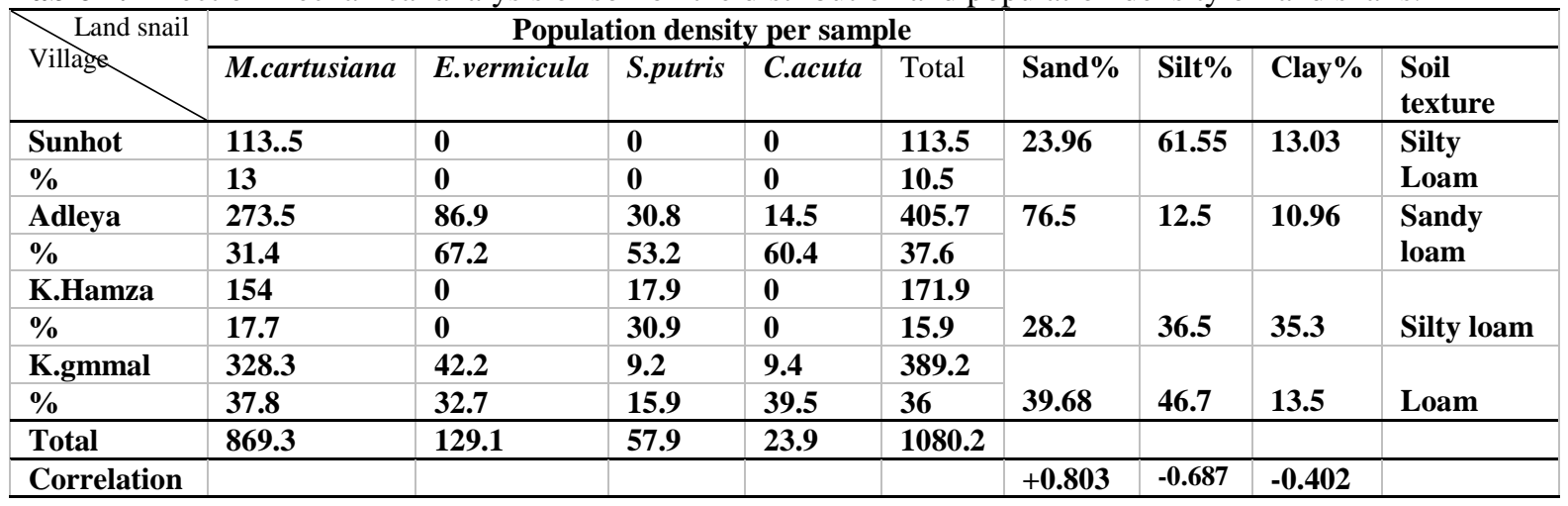

\section{4-2- Effect of chemical structure of soil.}

The results in Table (5) explains the relationship between the distribution and population density of the snails, and the chemical analysis of soil in the studied localities. It was revealed that the total average population density of snails (405.7 and $37.6 \%$ ) in Adleya village was higher than in other villages. Moreover, Adleya had the highest concentration of calcium in the soil (14425) ppm. The general average population density of snails in Sunhot was (113.5 and $10.5 \%$ ), which was the lowest one compared to other villages, but the value of $\mathrm{pH}$ (8.23) and E.C (1.45) $\mathrm{ds} / \mathrm{m}$ increased in its soil. In addition, Sunhot village was the lowest in concentration of calcium (2530) $\mathrm{ppm}$. The results of the chemical analysis of the soil in Kafr Al-Gammal are similar to the results of the soil of the Adleya village, in both E.C (0.903 and 1.04 $\mathrm{ds} / \mathrm{m}$ ) and $\mathrm{pH}$ value (7.77 and 7.65), but differ in calcium concentration (3500 and $14425 \mathrm{ppm})$, respectively. Kafr Hamza soil was the lowest in E.C (0.34) ds /m, although it ranked third after both Adlya and Kafr Al-Gammal in the population of snails (15.9\%).

Table 5. Effect of chemical analysis of soil on the distribution and population density of land snails.

\begin{tabular}{|c|c|c|c|c|c|c|c|c|}
\hline \multirow{2}{*}{$\begin{array}{l}\text { Land snail } \\
\text { Village }\end{array}$} & \multicolumn{4}{|c|}{ Population density per sample } & \multirow[t]{2}{*}{ Total } & \multicolumn{3}{|c|}{ Chemical analysis } \\
\hline & M.cartusiana & E.vermiculata & S.putris & C.acuta & & E.C(ds/m) & pH & $\mathrm{Ca}$ (ppm) \\
\hline Sunhot & $113 . .5$ & $\mathbf{0}$ & $\mathbf{0}$ & $\mathbf{0}$ & 113.5 & \multirow[b]{2}{*}{1.45} & \multirow[b]{2}{*}{8.23} & \multirow[b]{2}{*}{2530} \\
\hline$\%$ & 13 & $\mathbf{0}$ & $\mathbf{0}$ & $\mathbf{0}$ & 10.5 & & & \\
\hline Adleya & 273.5 & 86.9 & 30.8 & 14.5 & 405.7 & \multirow[b]{2}{*}{1.04} & \multirow[b]{2}{*}{7.65} & \multirow[b]{2}{*}{14425} \\
\hline$\%$ & 31.4 & 67.2 & 53.2 & 60.4 & 37.6 & & & \\
\hline K.Hamza & 154 & $\mathbf{0}$ & 17.9 & 0 & 171.9 & \multirow[b]{2}{*}{0.34} & \multirow[b]{2}{*}{7.51} & \multirow[b]{2}{*}{2710} \\
\hline$\%$ & 17.7 & $\mathbf{0}$ & 30.9 & $\mathbf{0}$ & 15.9 & & & \\
\hline K.gmmal & 328.3 & 42.2 & 9.2 & 9.5 & 389.2 & \multirow{2}{*}{0.903} & \multirow{3}{*}{7.77} & \multirow[b]{2}{*}{3500} \\
\hline$\%$ & 37.8 & $32.7 \%$ & 15.9 & 39.5 & 36 & & & \\
\hline Total & 869 & 129.1 & 57.9 & 23.9 & 1080.2 & & & \\
\hline Correlation & & & & & & -0.63 & -0.52 & +0.66 \\
\hline
\end{tabular}

EC: Electrical conductivity

Statistical analysis showed that the average general population density of snails is positively correlated with concentration of calcium, but negatively correlated with value of both E.C and $\mathrm{pH}$ value in soil. Idohouet al. (2013) mentioned that the most parsimonious GLM model showed that the abundance of $A$. fulicawas positively associated to fine sands, fine silts and $\mathrm{pH}$, while the interactions were negatively associated with the abundance of the 
species. The abundance of L. flammea was negatively associated with fine sands, fine silts and $\mathrm{pH}$, while the interactions were positively associated with the $A$. Marginata. The abundance was negatively associated with fine silts, $\mathrm{pH}$ and litter, while the interactions were positively associated with the abundance of the species. The abundance pattern of forest molluscs is likely to be affected by different processes.

\section{Conclusion}

Results from this study showed that Monacha cartusiana land snail was the highest in density in the tested governorates. Statistical analysis showed that the average general population density of snails was positively correlated with the proportion of sand and calcium in the soil, while negatively associated with silt, clay, $\mathrm{pH}$ and E.C.

\section{References}

Asran, F. D. (2001). Evaluation and implementation of novel and environmentally safe approaches in IPM programme for terrestrial snails. Ph. D. Thesis, Institute of Environ, Studies, and Res., Ain Shams Univ 199 pp.

Awad, M.H.M.; Fouad, M. M. and Abd ElGalil,Y.M.A. (2012). Effect of limiting periods on the population density of certain land snail and slug species in Egyptian clover Field at Damietta Governorate. Assiut J. of Agric. Sci., 43(1): 96103 pp.

Awad, M.H.M. (2014). Seasonal activity of land snails and slugs on lemon and guava trees at Damietta and Kafer El Batikh districts, Damietta Governorate. J. Plant Prot. and Path., Mansoura Univ., 5(6): 705-715.

Baker, G.H (1988). Population dynamics of white snails (Mollusca: Heliciae ), introduced pest in Australia. CSIRO. Aust. Div. Entpmol. Tech., (25): 1-31.

Clark, J. A. and May, R.M. (2002). Taxonomic bias in conservation research. Science 297: 191-192.

Eshra, E.H. (2013). Survey and distribution of terrestrial snails in fruit orchards and ornamental plants at Alexandria and EL-Behira Governorates, Egypt, Alex. Sci. Exchange J.34 (2); 242-248.

Giokas, S.; P. Karkoulis; Rafilis, P. andValakos, E. (2007). Relictual Physiological ecology in the threatened land snail Cordinglonia helenae. A cause for decline in changing environment. Acta Ecological 32:269-278.

Godan, D. (1983). Pest slugs and snails: Biological and control. Springer, Verily, Berlin Heidelberg. New York, 1- 445pp.

Idohou, R.; Djagoun, C.A.; Kassa, B.; Assogbadjo ,A. E. and Codjia, J. T. (2013).Soil factors affecting density of three giant land snail species in different habitats of Dassa-Zoume` district . Q. Science Connect 31:1-10 .

Mohamed, Gh.R. (2015). Incidence of Land snails in habiting different vegetation at some Governorates in North East of Delta Egypt. J. Plant prot.and Path., Mansoura univ., 6(6): 899-907.

Mortada, M. M. (2002). Ecological, biological and control studies on crtain terrestrial gastropods in Dakahllia Governorate. Ph.D. Thesis, Fac. Agric., Zagazig. Univ., 183 pp.

Millar, A.J. and Waite, S. (2002).The relationship between snails, soil factors and calcitic earthworm granules in a coppice woodland in Sussex. Journal of Conchology, 37, 483-503.

Rady,G.H.;Abdelgawad, A.A.; Ismail, SH.A.andLokma. M.H. (2014). Ecology of some terrestrial mollusks in Sharkia governorate Egypt. J. Agric. Res., 92 (3): 907-920.

Sandeep, S.; G. Ravikanth andAravind,N.A.. (2012). Land snails (Mollusca: Gastropods) of India: ststus, threats and conservation strategies. Journal of Threatened Taxa 4(11): 3029- 3037.

Shahawy, W.A.; Hendawy, A.S., Abada, A, E. and Kassem, A. A. (2008). Land snails infesting rice plants and their accompanied Parasitoids and Predators at Kafer EL-Sheikh Governorate, Egypt. Egyptian J. Agric. Res., 86: 971-980.

Shetaia, S.Z.S.; Ismail, Sh. A.A.; and Abdel-Kader, S. M. (2009). Survey, population dynamics and importance value of certain Land snail species infesting different crops in Sharkia Governorate. Egypt. Acad. J. Biology. Sci.,1 (1): 37-43.

Woogeng, I. N.;Grobler, J. P; Etchu, K. A. and Ndamukong, K. N. (2013). The perception of climate and environmental change on the performance and availability of the edible Land snail; a need for conservation. African Journal of Agricultural Research, 8(11): 1457-1465. 


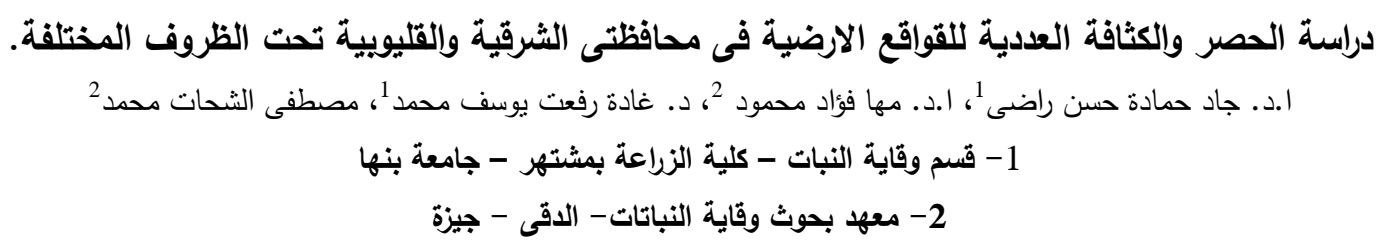

أجريت هذه الدراسة في أربع قرى وهى سنهوت وعدليه بمحافظة ألثرقيه وكفر الجمال وكفر حمزة بمحافظة القليوبية في الفترة من 2014 إلى الى

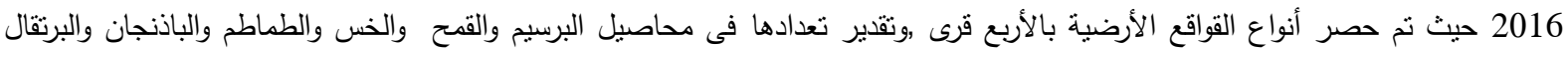

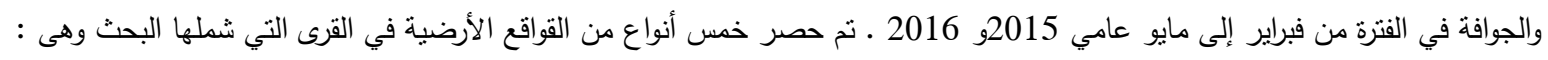
Monacha cartusiana (Müller), Succinea putris (Linnaeus), Eobania vermiculata (Muller), Cochlicella acuta

(Muller).

واختلفت الكثافة العددية لها وتوزيعها بين الححافظات وداخل القرى نفسها ومن محصول إلى أخر حيث سجلت محافظة القليوبية اجمالى تعداد

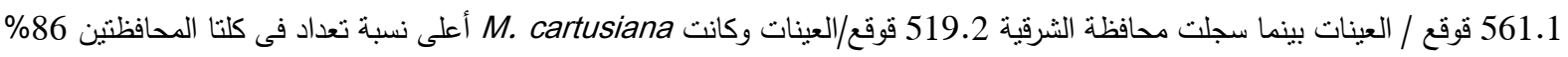
فى القليوبيه و74.5\% في الثرقية وكانت اقل نسبة اعداد للقوقع الثعات

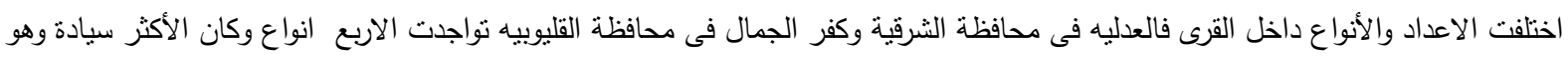
M. cartusiana كوعين فقط هما S. putris و M. cartusiana

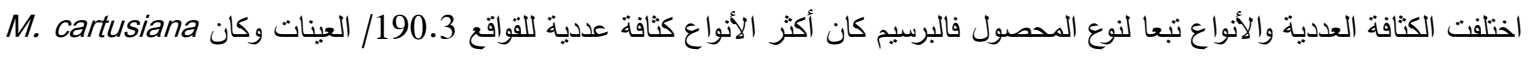

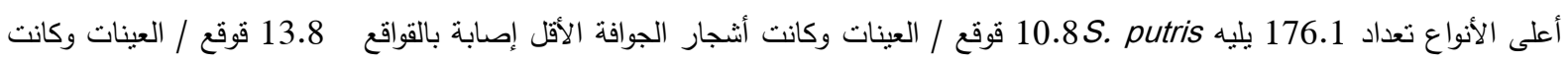

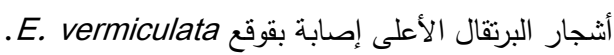

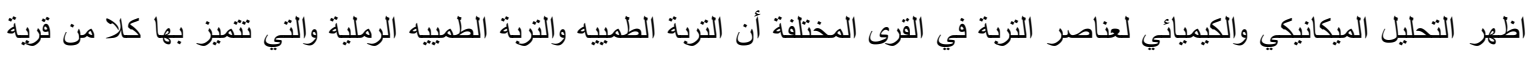

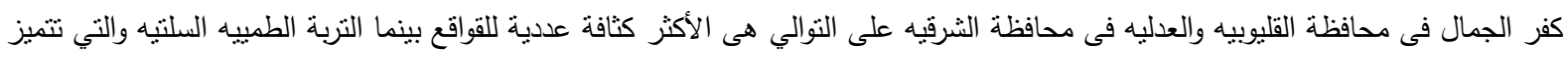

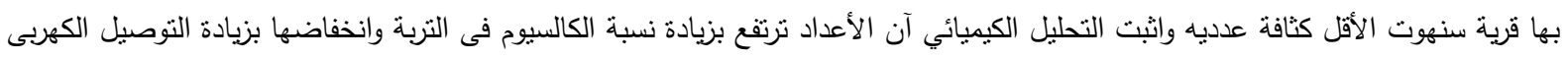

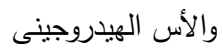
التحليل الاحصائى لدراسة الارتباط بين مكونات التربة الميكانيكية والكيميائية أشار إلى وجود علاقة ايجابية بين نسبة الرمل في التربة والكية والكثافة

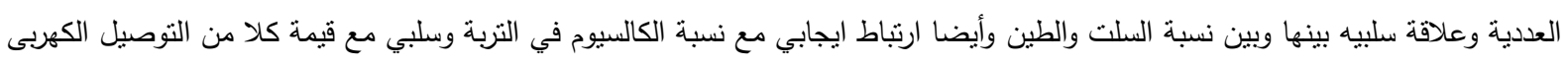
والأس الهيدروجينى . 